Research Paper

\title{
The Effect of Choice Theory Training to Parents on the Aggression of their Children in Elementary School
}

\author{
Leila Chegini ${ }^{1}$, Mohammad Ismaeel Ebrahimi*2, Ali Sahebi ${ }^{3}$
}

1. M.A in Clinical Psychology, Department of Psychology, Hamedan Branch, Islamic Azad University, Hamedan, Iran

2. Assistant Professor, Department of Psychology, Hamedan Branch, Islamic Azad University, Hamedan, Iran

3. Ph.D. in Clinical Psychology, Senior Instructor and Research Scientist, Institute for Choice Theory and Australian Reality Therapy

Accepted: June 11, 2018

\begin{abstract}
Background and Purpose: One of the most common problems of elementary school children is aggression which has a direct relationship with parental attitudes and parenting styles. The purpose of this study was to investigate the effect of choice theory training to mothers on aggression of their children in elementary school.

Method: This semi-experimental study was of pretest-posttest control group design. The statistical population of the study consisted of all mothers of elementary school students who were studying in Hamedan district in the academic year of 2016-2017. After three months of observing the students' behavior and interviewing with the teachers, a sample of 30 mothers was selected using purposeful sampling. Subjects were then randomly assigned into two groups of 15 subjects. The instrument used in this study was the parent form of the children aggression questionnaire (Vahedi, Fathi A'zar, Hosseini Nsab, and Moghaddam 20). The data were analyzed by SPSS software and multivariate covariance statistical test.

Results: The findings of this study showed that the choice theory training to mothers affects their children's aggression ( $\mathrm{P}<0.01)$, so that the verbal, physical, and relational aggression significantly decreased in the experimental group, but no significant changes were observed in the control group.

Conclusion: According to the findings of this study, it can be concluded that due to the motivational nature, and change of beliefs, thoughts and attitudes, choice theory training can lead to decrease of aggression in children.
\end{abstract}

Keywords: Aggression, choice theory training, students, mothers

Citation: Chegini L, Ebrahimi ME, Sahebi A. The effect of choice theory training to parents on the aggression of their children in elementary school. Quarterly Journal of Child Mental Health. 2019; 6(1): 70-82.

*Corresponding author: Mohammad Ismaeel Ebrahimi, Assistant Professor, Department of Psychology, Hamedan Branch, Islamic Azad University, Hamedan, Iran.

Email: Ms_ebrahim@iauh.ac.ir

Tel: (+98) 813-34297512 


\title{
تأثير آموزش تئورى انتخاب به والدين بر يرخاشكرى فرزندان دانش آموز آنها در دوره ابتدايى
}

\author{
ليلا جكينى '، محمد اسماعيل ابراهيمى"'، على صاحبى" \\ ا. كارشناسى ارشد روانشناسى، دانشكده علوم انسانى، واحد همدان، دانشكاه آزاد اسلامى، همدان، ايران

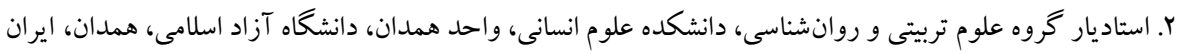

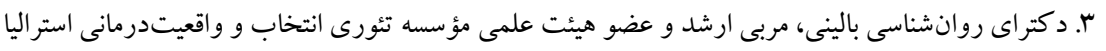

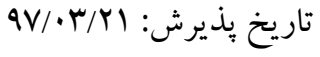

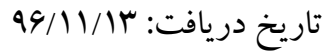

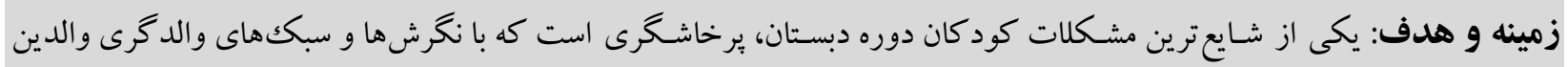

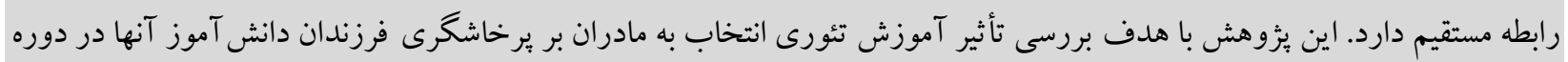
ابتدايى انجام شد.

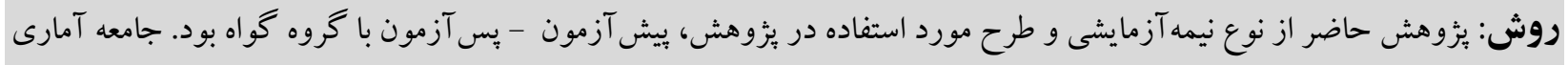

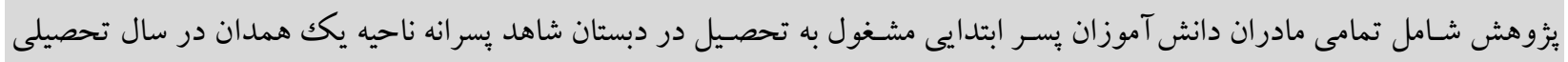

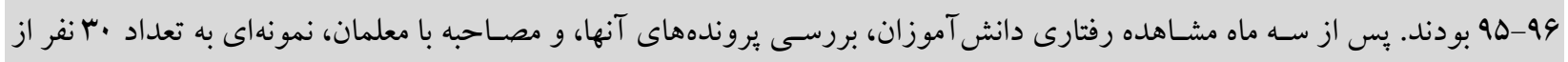

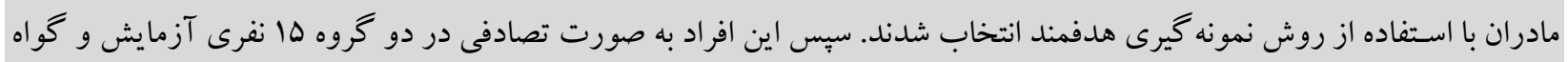

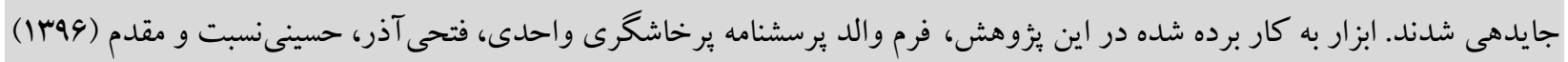

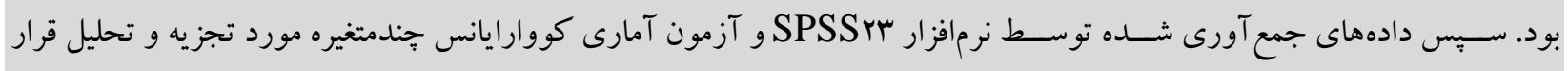
كرفت.

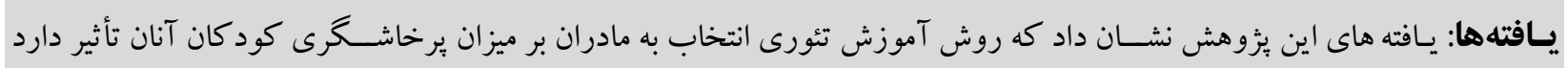

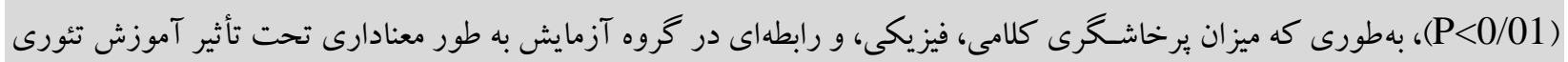

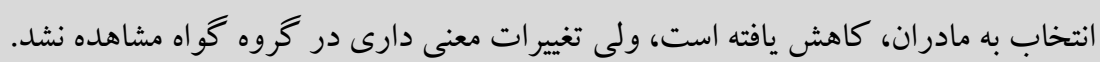

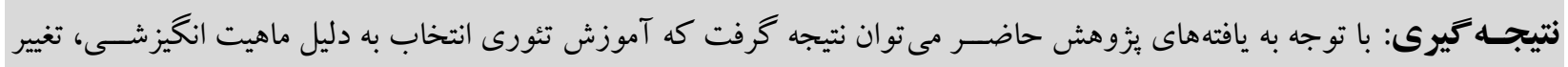

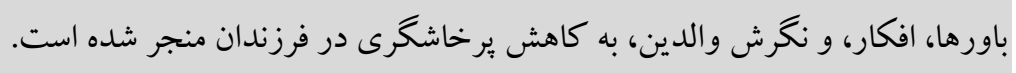
كليد وازهها: برخاشكرى، آموزش تئورى انتخاب، دانش آموزان، مادران 
رفتارى تعريف شده است كه به وسيله تقويتهاى بيرونى مهار

مقدمه

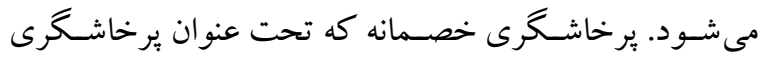
دوران دبستان زمان مناسبى براى تشخيص مشكلات عاطفى،

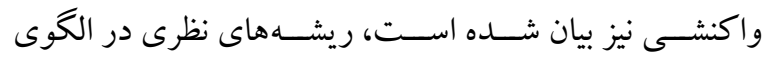

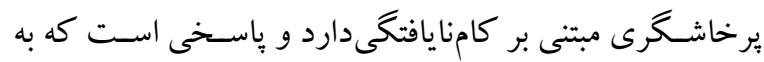

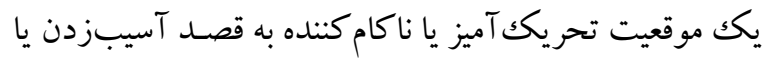

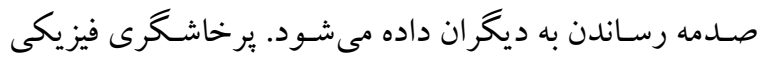

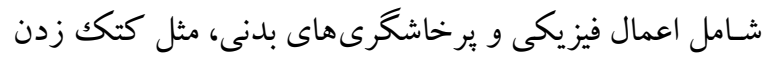

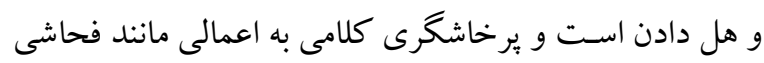

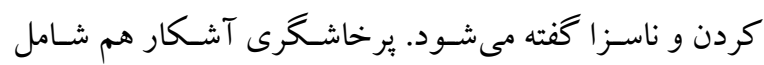

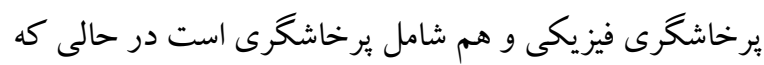

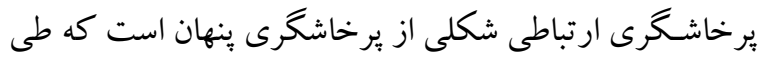

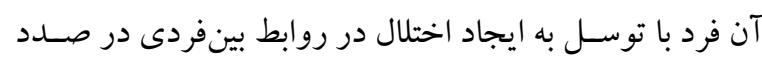

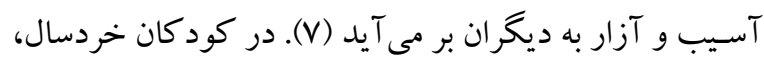

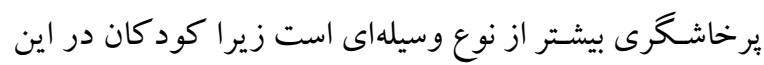
سـين احسـاس مالكيت نسـبت به متعلقات خود دارند. به طور

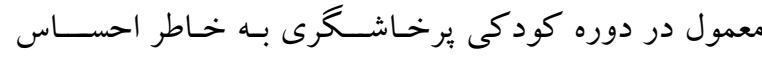
كامنايافتكى و عدم امكان دسـترسى به خو اسـته ها و نيازهاى

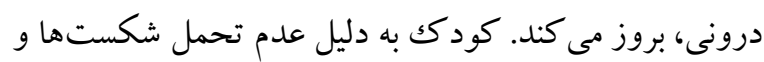

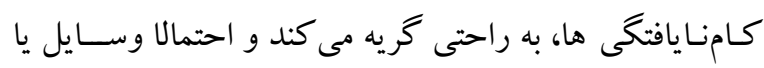

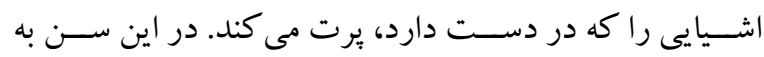

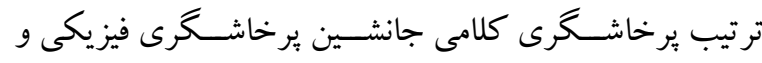

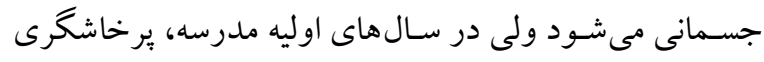

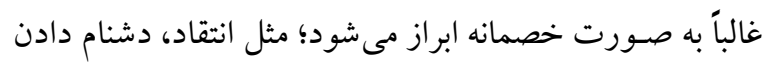

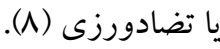

عوامـل مختلفى مى تواندل با بروز اختلالات رفتارى از جمله

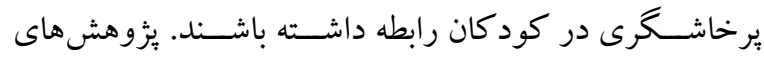

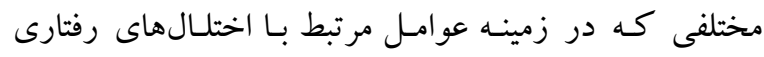
كود كان صورت كرفته اسـت، اغلب اين نتيجه را در برداشته كه اختلالهاى رفتارى كود كان، بيشـتر حاصـل نحوه ارتباط والـدين با كودكك اسـت تا عوامل ارثى و زيسـتى (9)؛ و و 
نظريه انتخاب در سال 1991 توسط كلاسر ^ يايهريزى شد و در آن بر نياز اسـاسى انسـان (بقاء، عشـق و تعلق، قدرت،

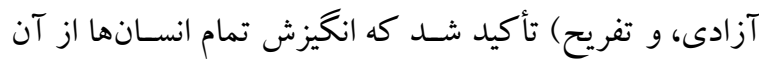
نشات مى گيرد. افر اد با توجه به دنياى مطلوب خون خود و مقايسه آن باواقعيتى كه از دنيا دركى كردهاند، به صـورت بهورد كاملاً هوشــمندانه رفتارهايى را براى نيل به نيازهايشــان انتخاب

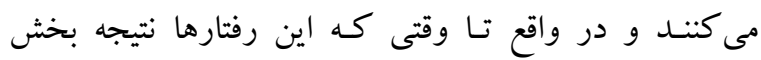

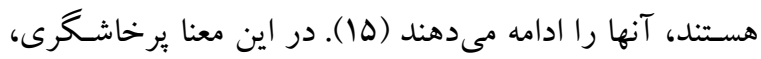

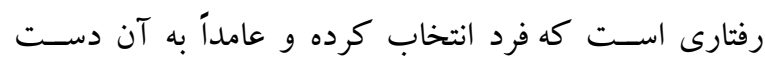
مىزند. بر طبق همين نظريه ممكن اسـت بعضى رفتارها براى يكك هدف نتيجهبخش ولى براى ساير نيازها، ناكار آمد باشند؛

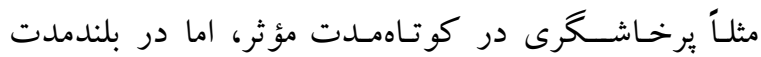
ناكار آمد و زيانبخش اسـت. طبق اصسول تئورى انتخاب تنها للازم است تا با تغيير و اصلاح دنياى كيفى و ادراكى فرد، اين

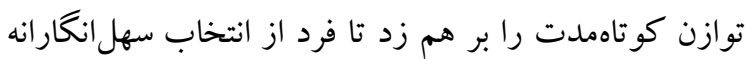

دست برداشته و رفتار مؤثر ديخرى را انتخاب كند (19).

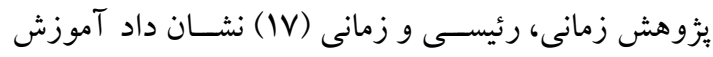

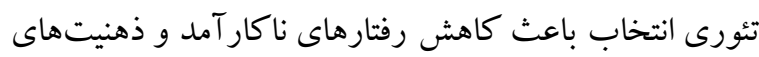
روانشناختى والدين شده است. نتايج مطالعات ديخر نيز نتايج

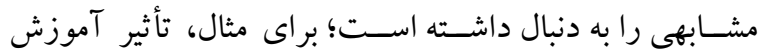

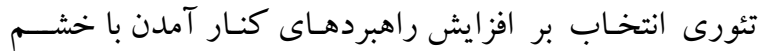

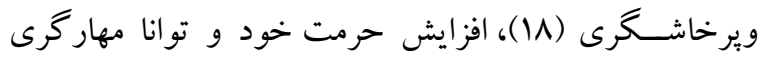

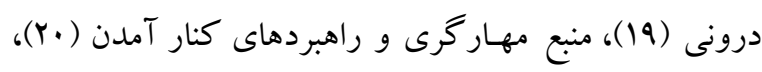

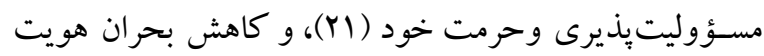
(YY) نظريه انتخاب مى گويد ما بيش از آنجه تصـور مى كنيم، بر

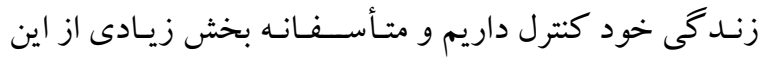

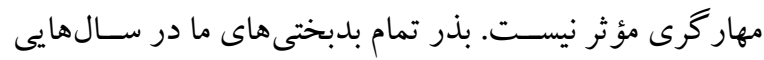

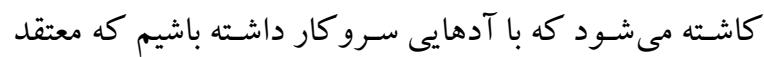

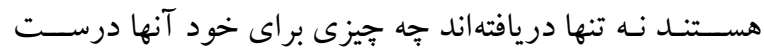

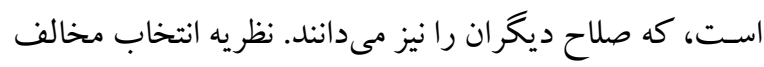

2. Glasser
يُزوهشـُ ان نتيجه گُرفتهاند كه بين سوءرفتار والدين و اختلال رفتارى كودك، ارتباط مثبت وجود دارد و اين رابطه نشــان دهنده اين موضـوع اسـت كه عامل خانوده و خصـوصـاً رفتار والـدين در دوران كودكى نقش مهمى در بروز اختلالهاى مورهو رفتارى در كودكى و بزر گسالى دارد (·•). بنـابر اين با توجه به اهميت نقش والدين در تربيت فرزندان

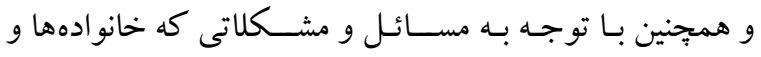

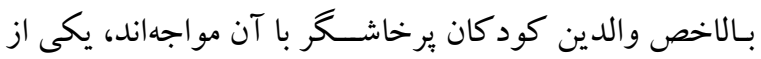

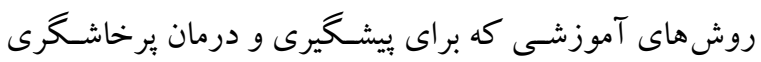
كود كان مى تواند مفيد باشــ، آموزش والدين اسـت (1) لـ اين روش كه بر اصسول ياد كيرى اجتماعى مبتنى اسـت به والدين

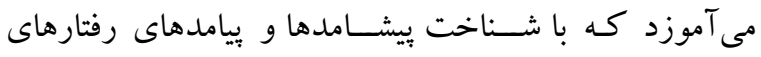

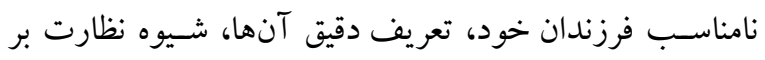

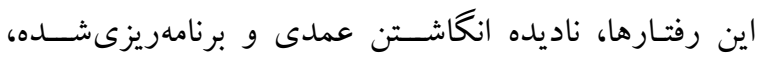
محروميت موقت و ديخر فنون غيرتنبيهى، رفتارهاى فرزندان خود را تغيير دهند و رفتارهاى مناسـب را به وسـيله توجه

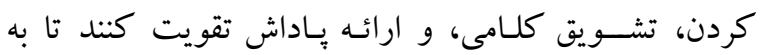
رفتارهاى دلخواه، دست يابند (r) (I). روانشـناسـان باور دارند واكنش هاى متقابل و صـميميت والدين اســاس تحول شــناختى - عاطفى كودك را تشــكيل

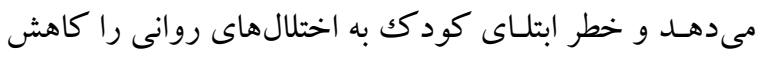

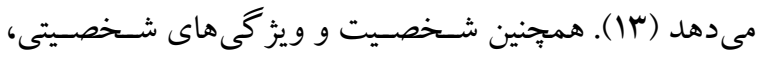
وضعيت بهداشت و سلامت روان والدين به خصوص مادران با

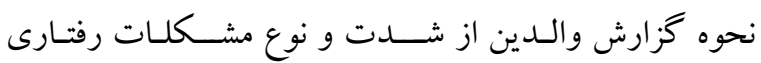

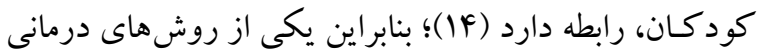
كه براى درمان و يِيشخيرى رفتارهاى برخاشخر انه در كود كان

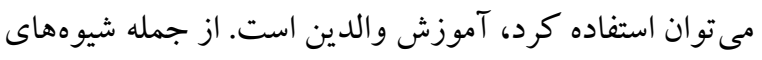
آموزشــى والـدين كـه مى توانــ نقش مهمى دور كـاهش ميزان اختلالات رفتارى كود كان داشته باشد، آموزش تئورى انتخاب'

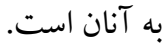
1. Choice theory 
توجه به آنجه اشـاره شد و از آنجا كه تاكنون بُروهش جِندانى

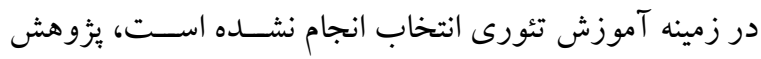

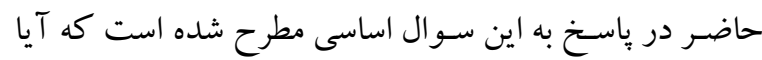

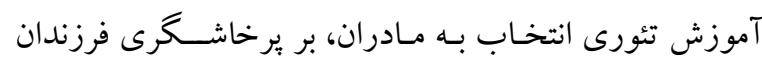
دانش آموز آنان تأثير دارد؟ تورى الثاب

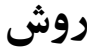
الف) طرح هزوهش و شـر كت كنند كان: يُزوهش حاضـر از نوع نيمه آزمايشسى و طرح مورد اسـتفاده از نوع بيش آزمون و

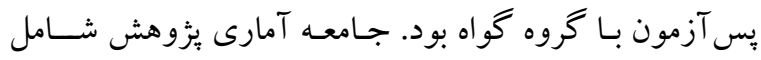
تمامى مادران دانش آموزان يسـر ابتدايى مشغول به تحصيل در برد

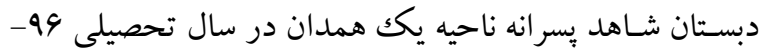

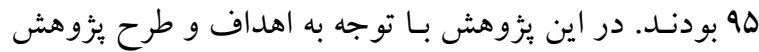

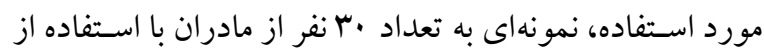

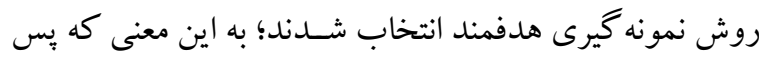

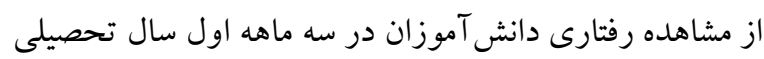

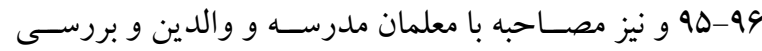

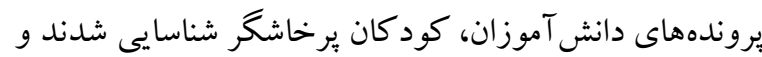

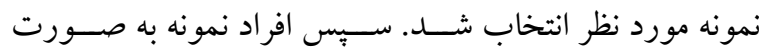
تصادفى در دو گروه آزمايش و گُواه جايدهى شدند (هر خروه

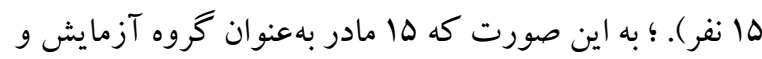

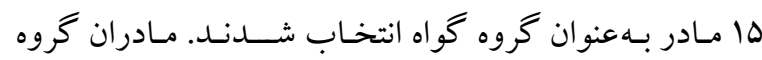

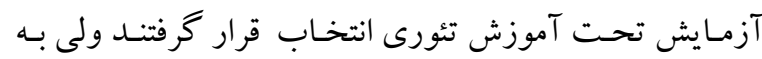

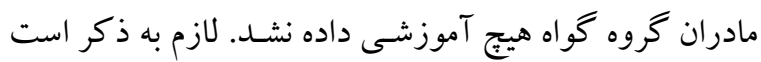

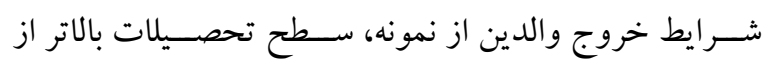
كارشناسى ارشد و تخصص روانشناسى بود.

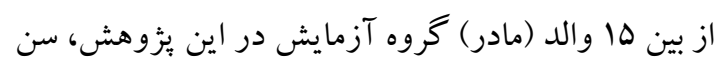

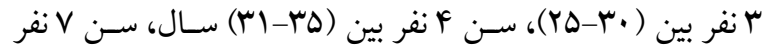

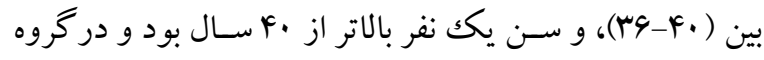

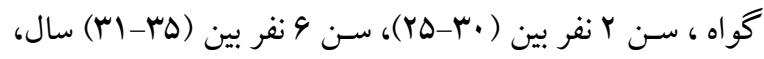

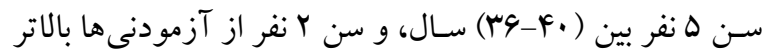

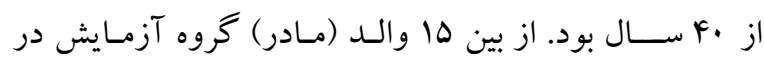

سـتت باستانى "من صلاح تو را مىدانم" است. به اعتقاد كلاسر

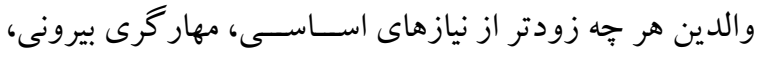

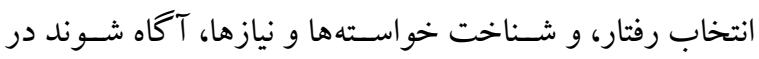

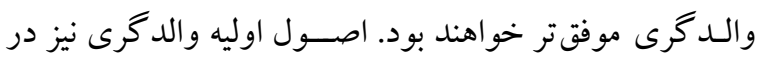
تئورى انتخاب عبار تسـت از عشـق و محبت بسـيار و عدم تنبيه

كلاسر (YF) در كتاب تئورى انتخاب به وضوح ارتباط بين اين تئورى را با عشق و محبت و سبكك والدگرى مقتدرانه بيان

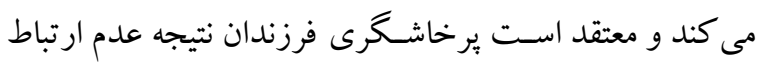

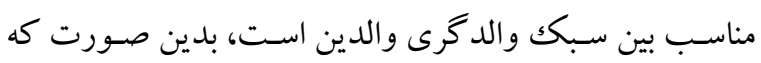

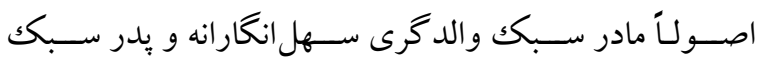
والدگرى برخاشگر انهاى دارد.

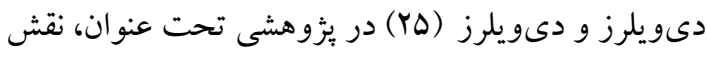
زبـان در تحول فرزنـدان نشــان داد، بين زبان بدنى (رفتارهاى

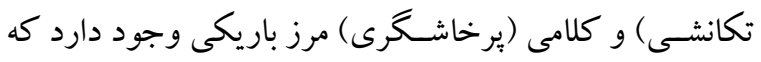
والدين انتخاب مى كنند با كدام يكك از اين دو زبان با فرزندان

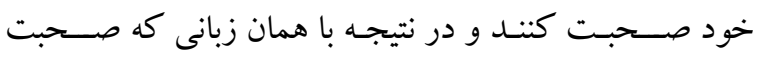

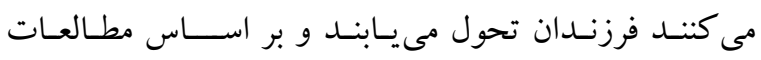

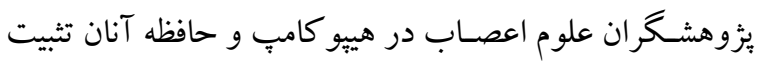

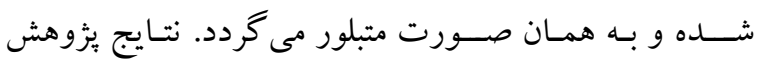
مهديانفر، كيميايى و قنبرى حسـام آبادى (YY)، وندنبيل (YV) و كوســو (YN) نيز به بررسـى رفتارهاى والدين و حضــور در

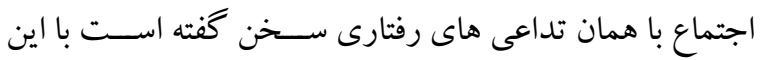

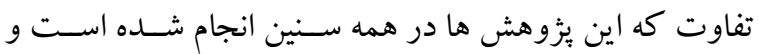
يُروهش كنونى بر روى دانش آموزان انجام گَرفته است.

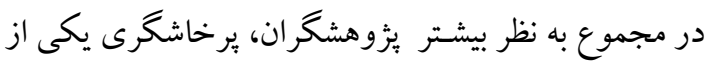

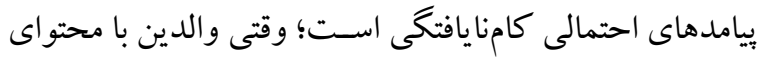

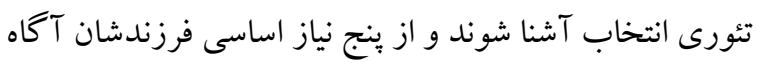

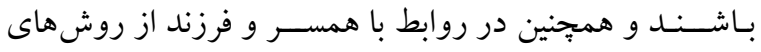

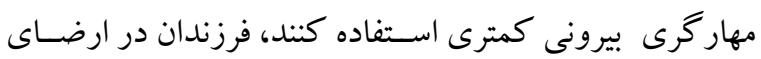
نيـازهـاى خود كمتر كـامنايـافتكى را تجربه كرده و در نتيجه

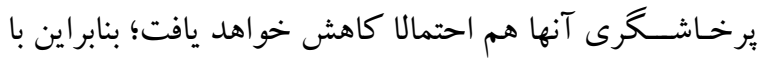


كرونباخ در كل مقياس 9 / • به دسـت آمد كه مىتوان كفت اين مقياس از اعتبار مطلوبى برخوردار اسـت. همجنين ضـريب آلفاى كرونباخ براى برخاشـخرى كلامى تهاجمى، فيزيكى -

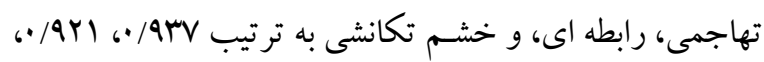

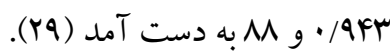
ج) برنـامه مداخلهاى: تئورى انتخاب به عنوان يكك شــاخه

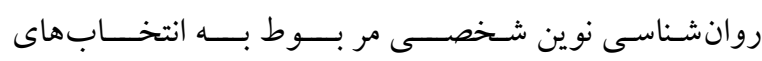

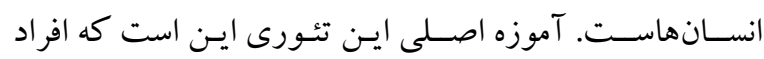

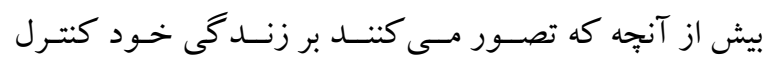

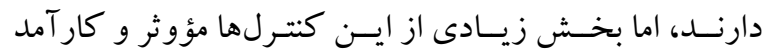
نيسـت. طبق ايـن تئسورى تمــام كارهـائى كـهـ افر اد انجـام

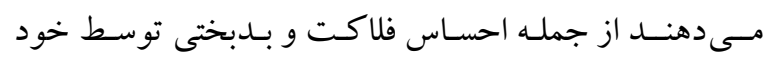

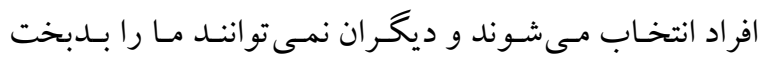

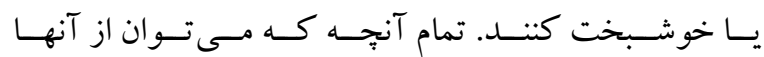

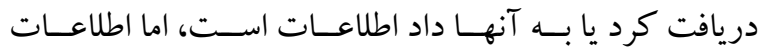
نمسى توانــــــه خـودى خـود در فرد احسـاس يـا عملى ايجـاد كند. افراد با بردازش دادههايى كه وارد مغز مسىشـود، تصـميم

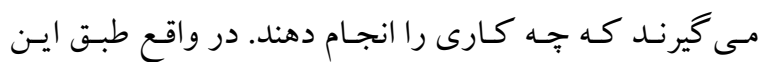

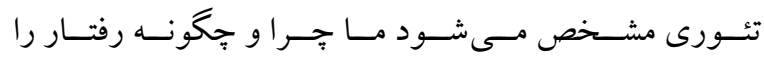

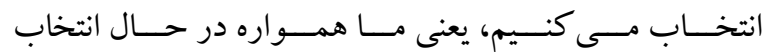
جֶ) برنامه آموزشى در جلسات مختلف ارائه شده است.
يثزوهش، ץ نفر تحصيلات زير دييلم، 1 نفر تحصيلات دييلم، و F نفر داراى تحصيلات دانشگاهى بودند. از طرفى از بين ها نفر

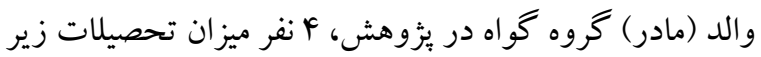
دييلم، 1 نفر تحصـيلـات دييلم، و بنفر داراى تحصـيلـات

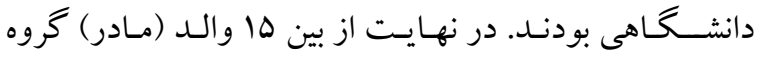
آزمايش در يزوهش، \& نفر داراى يكك فرزند، ^منفر داراى دو

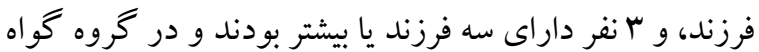

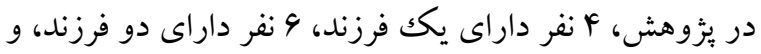
ه نفر داراى سه فرزند يا بيشتر بودند.

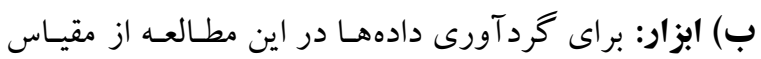
يرخاشخرى كود كان واحدى، فتحى آذر، حسينىنسب و مقدم (IrAV)

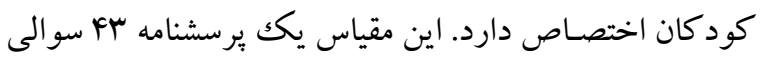
اسـت كه توســط مربى يا والدين كود كك تكميل مىشــود و شـامل يكك نمره كلى و جهار خردهمقياس اسـت كه عبارت بـاند

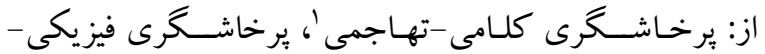

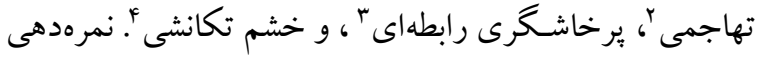

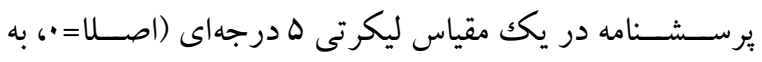

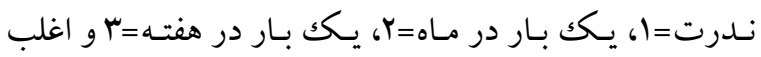
روزها= F) انجام مىشـود كه نمره هر خردهمقياس از جمع نمره ســـوالـات مربوطه و نمره كـل از جمع تمـامى خردهمقيـاس ها بهدست مى آيد (Y9). ضـريب پيايايى برسشنامه به روش آلفاى

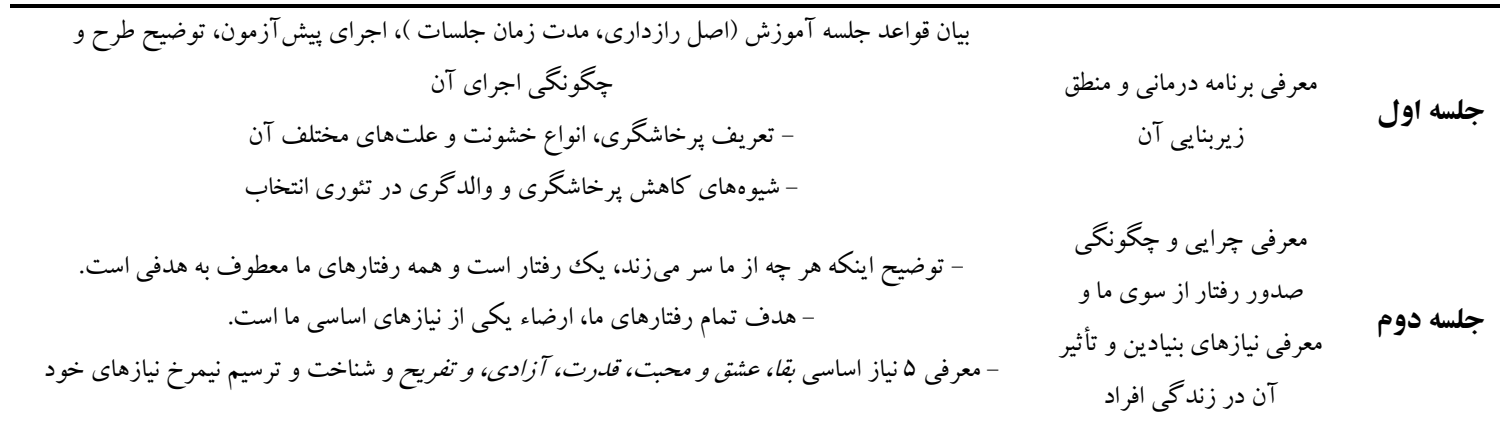

3. Relational aggression

4. Impulsive anger
1. Verbal-aggressive aggression

2. Physical-aggressive aggression 


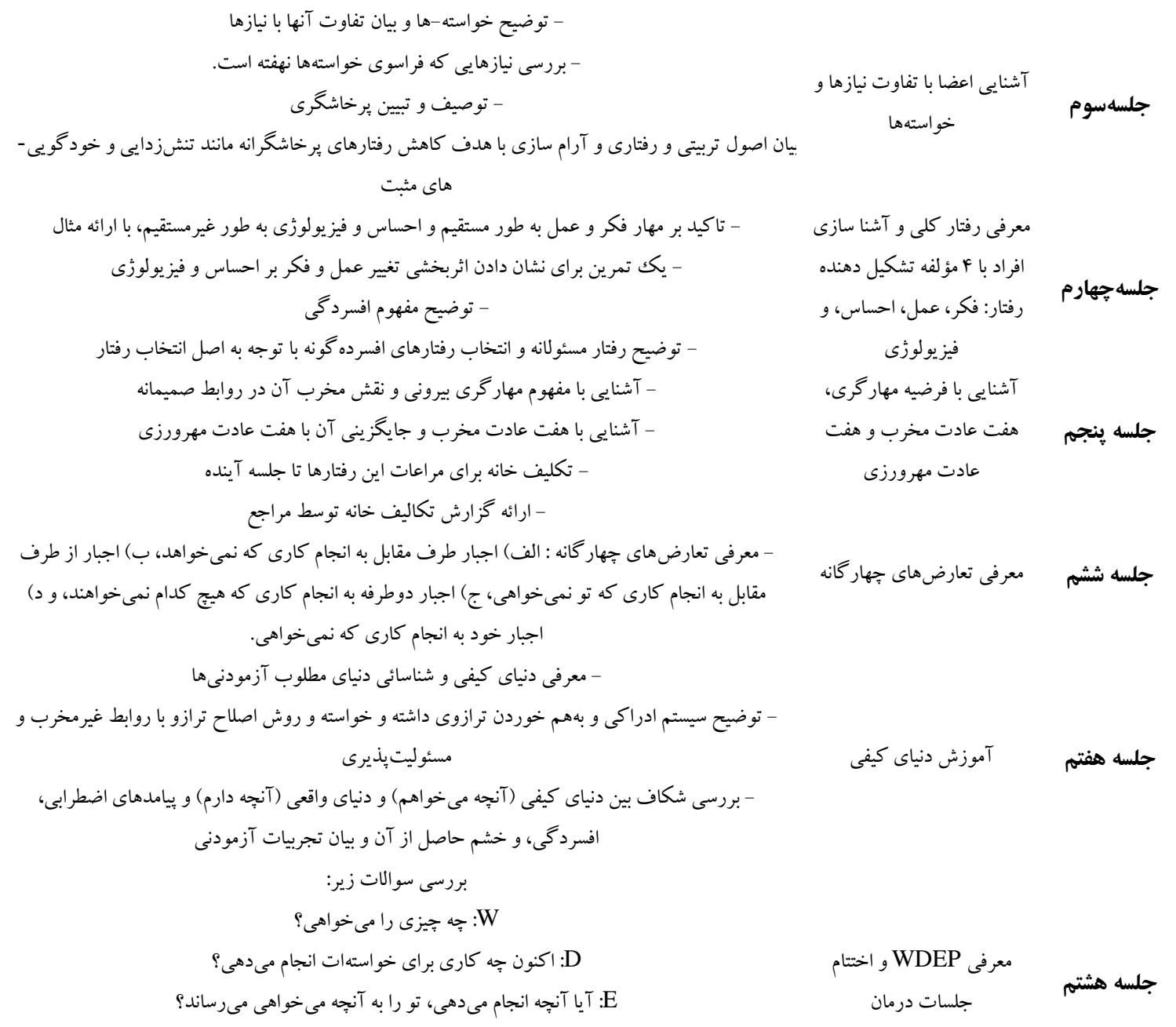

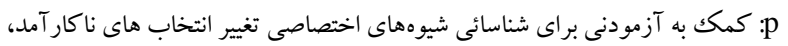

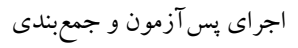

مطرح شده توسط انجمن روانشناسى ايران و آمريكا و سازمان

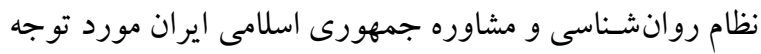

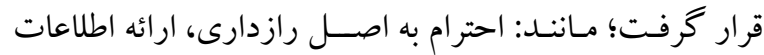

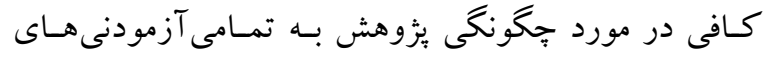
شـر كت كننده، كسـب رضـايت نامه كتبى به منظور شر كت در در

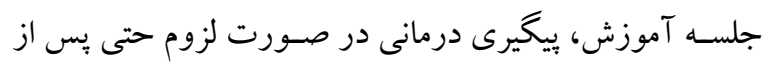

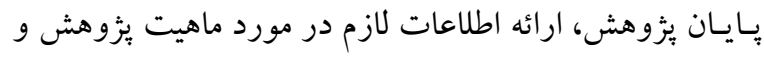
اطمينانبخشـى درباره محرمانه بودن نتايج، و امكان انصـراف آزمودنى ها در صورت عدم تمايل به همكارى در هر مرحله از ئزوهش.
د) روش اجرا: يس از كسب مجوزهاى للازم و كسب رضايت

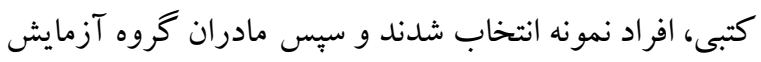
در معرض متغير مستقل (آموزش تئورى انتخاب) در م جلسـهـ

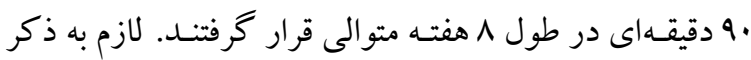
است يُزوهشخر خود مدرس دورههاى آموزشى تئورى انتخاب بودهه و آموزش را تحت نظارت استاد راهنما در هياييز و زمستان

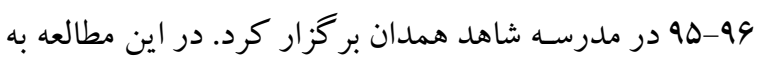

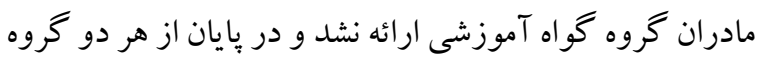

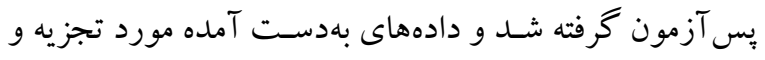
تحليل قرار خرفت. لازم به ذكر است كه در اين مطالعه تمامى كدهاى اخلاقى 


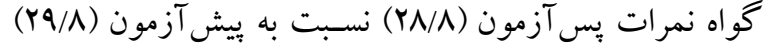

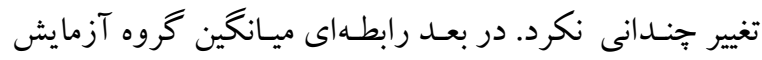

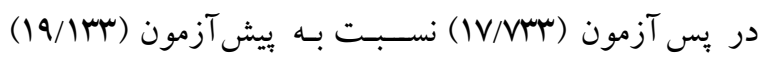

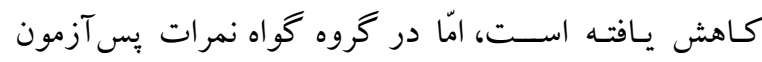
(IN/NTr)

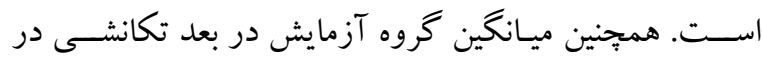

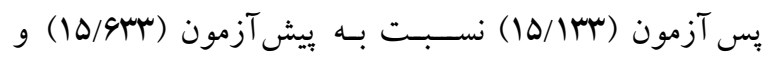

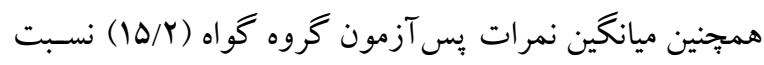

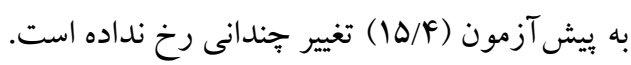
جهـت بررسـى معنـادارى نتايج بهدســت آمده از آزمون

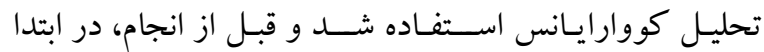

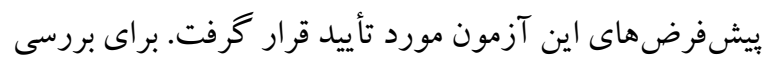

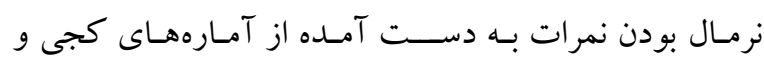

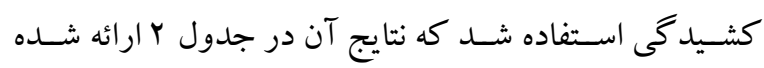

دادههاى بهدسـت آمده از برسـشــنامهها در بيش آزمون و ״س آزمون بـا اســتفاده از روشهاى آمارى توصــيفى از قبيل

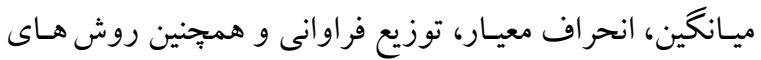

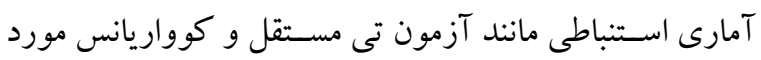
تجزيه و تحليل قرار كرفت. همجنين از نرمافزارهاى SPSS 23 در جهت تحليل دادهها استفاده شد.

\section{يافتهها} نتـايج تحليـل دادهها نشــان داد كه ميانخين گروه آزمايش در

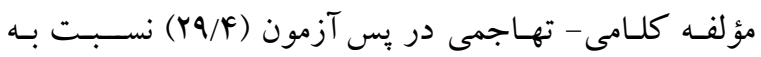

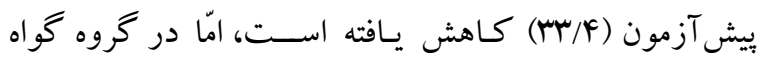

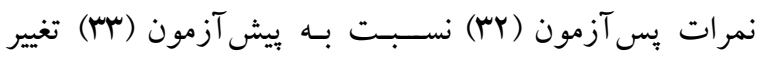
جندانى نيافته اسـت. همجِين نتايج نشان داد كه ميانگين گرووه

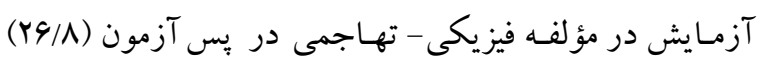

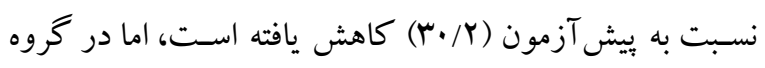

جدول r: كجى و كشيد

\begin{tabular}{llll}
\hline & & & \\
\hline \\
\hline
\end{tabular}

حاضـر رعايت شـده اسـت. در جدول سا، نتايج آزمون

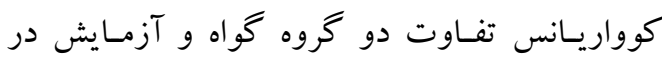
برخاشخرى گزارش شده است.
همـانطور كـه در جـدول Y مشــاهـده مىشــود همه

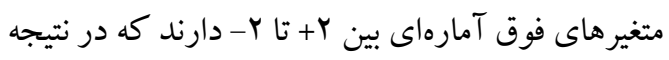

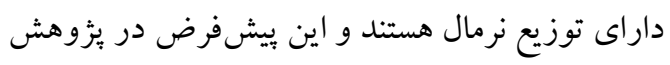


جدول rّ: نتايج آزمون كوواريانس تفاوت دو كروه كواه و آزمايش در يرخاشكرى

\begin{tabular}{|c|c|c|c|c|}
\hline ETA2 & سطح معنادارى & $\mathbf{F}$ & لامدا ويلكز & شاخصهاى آمارى \\
\hline$\cdot / \varphi \Delta \Delta$ &.$/ 1$ & F/Mar & $\cdot / D F \Delta$ & كروه \\
\hline
\end{tabular}

در نظر گرفتن مجذور اتا، مى توان كفت هـ/ • اين تغييرات يا

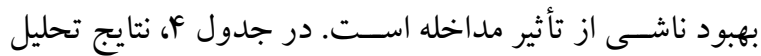

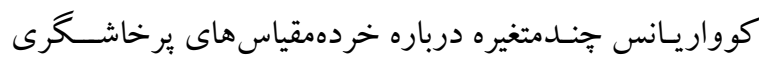
ارائه شده است.

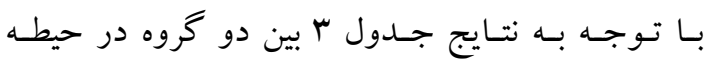

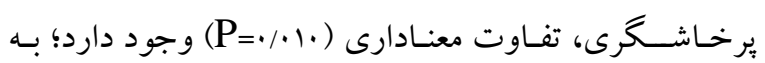
عبـارت ديخر، مى توان گفـت، تفــاوت بين نمره دو گروه، بيان كننده اين مطلب اسـت كه آموزش تئورى انتخاب به والدين

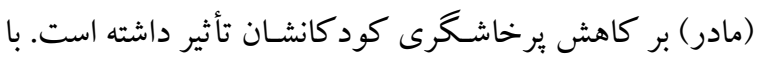

جدول ع: نتايج تحليل كواريانس جندمتغيره خردهمقياسهاى برخاشعرى

\begin{tabular}{|c|c|c|c|c|c|c|c|}
\hline اندازه اثر & سطح معنادارى & $\mathbf{F}$ & ميانكين مجذورات & درجه آزادى & مجموع مجذورات & متغير & منبع \\
\hline$\cdot / M F A$ & $\cdot / \cdots r$ & $|Y / \Lambda|^{4}$ & $9 N / \mu r$. & 1 & $9 N / \mu r$ & بعد كلامى -تهاجمى & \\
\hline . TrY & . & V/rG. & $F Y / Y F Q$ & 1 & FY/YFQ & بعد فيزيكى - تهاجمى & og \\
\hline.$/ Y V$ & . /FYO & .1909 & $\cdot / 4 \Delta 1$ & 1 & $\cdot / 401$ & بعد تكانشى & وروة \\
\hline$\cdot / \backslash \Delta \wedge$ &.$/ 4 \Delta$ & $F / F \wedge q$ & $\mathrm{~V} / 9 \mathrm{~A}$. & 1 & $\mathrm{~V} / 9 \Lambda$. & بعد رابطهاى & \\
\hline
\end{tabular}

كلامى كود كان شده است كه اين يافته با نتايج مطالعه مهديانفر و همكاران (Y9) با عنوان بررسى اثربخشى توانمندسازى روانى اجتمـاعى مبتنى بر نظريـه انتخـاب بر كـاهش برخاشـــرى و

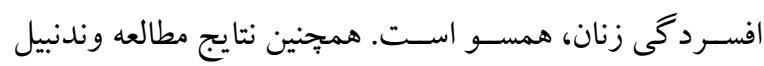
نشــان داده اســت والـدينى كه وقت بيشــترى صــرف (YV) فرزندانشـان مى كنند دار ای كود كانى هستند كه كمتر به سمت رفتارهاى يرخاشـكر انه گر ايش بيدا مى كنند. به اعتقاد كلاسـر و الدين هرجه زودتر از نيازهاى اسـاسى، عقايد مهارگرى (YF) بيرونى، انتخاب رفتار كلى، و تفاوت خواسته ها و نيازها، آكاه شـــونــد در برورش فرزندان خود موفق تر خواهند بود. آكاهى والدين از نيازهاى اسـاسى فرزندان موجب مىشود كه آنها را بر آورده كرده و فرزنـدان كامنايافتكى كمترى را تجربه كنند و در نتيجه رفتار يرخاشخرانه، كمتر فرصت ظهور مى يابد. تحليل دادههاى بهدست آمده در اين بزّوهش نشان داد كه آموزش تئورى انتخاب به مادران منجر به كاهش برخاشـرى فيزيكى كود كان شده است. در اين ارتباط اندرسون و اولويس

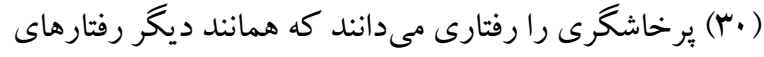

بر اسـاس نتايج بهدسـت آمده، آموزش تئورى انتخاب به

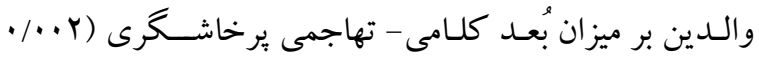

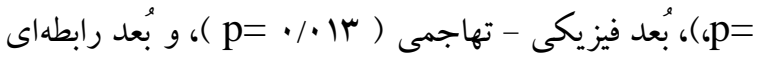

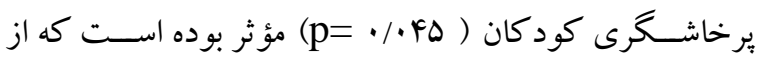
لحاظ آمارى نيز معنا دار است ولى بر بُعد تكانشى برخاشگرى

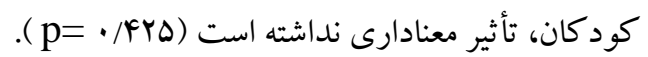

\section{بحث و نتيجه كيرى}

هدف از انجام يثزوهش حاضـر، بررسـى تأثير آموزش تئورى انتخاب به والدين بر يرخاشـكرى فرزندان دانش آموز آنها در مقطع ابتدائى بود. يافته هاى بهدست آمده نشان داد كه آموزش بـهـ مادران بر ميزان برخاشــرى كود كان آنان تأثير معنادارى دارد؛ بـه عبـارت ديخر، آموزش تئورى انتخاب به مادران، در ميز ان يرخاشگرى كود كان آنان، در گروه آزمايش تغيير ايجاد كرده است، در صورتى كه در گروه گواه، جنين تغييرى ديده نشده است.

بررسى دقيقتر نتايج در سطح خردهمقياس ها نشان داد كه آموزش تئورى انتخاب به مادران، موجب كاهش يرخاشـرى 
و كودك شـكل گر فته و نهادينه شـــده اســ، بنابر اين رفتار صحيح والد در كوتاهمدت نتوانسته تأثير مناسبى بر اين بعد از برخاشـرى كود كك داشته باشد. يكى ديخر از دلايل معنى دار

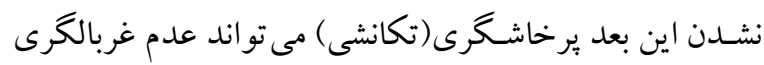

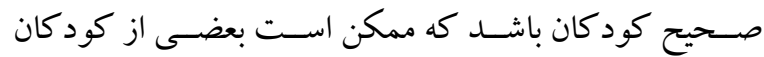

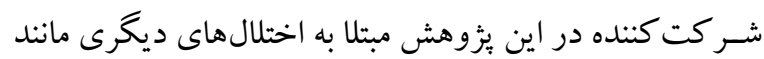
اختلال نارسـايى توجه/فزون كنشـى بوده باشـــــ كه رفتارهاى

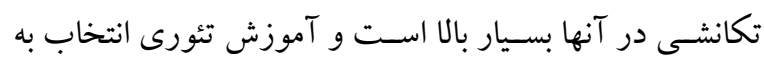
مادران آنها، به تنهايى در كاهش اين حيطه از برخاشخرى مؤثر نبوده است. در هر صـورت به طور كلى يافتهاى اين مطالعه نشـان داد

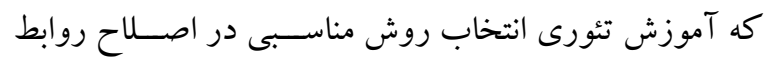

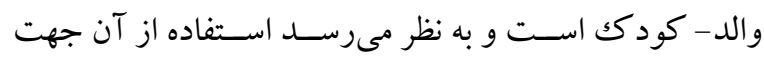

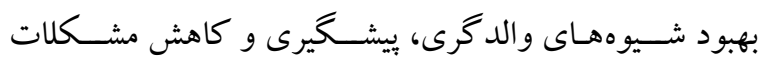

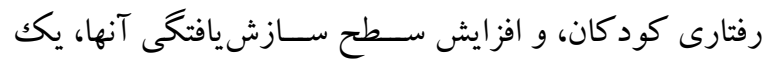

$$
\text { ضرورت اساسى است. }
$$

اين مطالعه داراى محدوديتهايى نيز بوده اسـت؛ از جمله يثزوهش حاضـر فقط بر روى مادران كود كان برخاشــر انجام

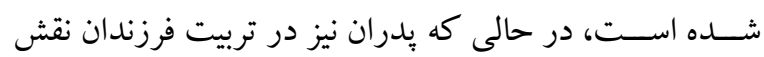

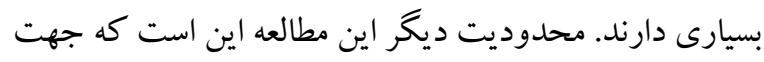

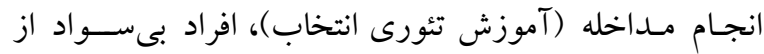
مطالعه خارج شـــند كه اين مى تواند باعث ســو گيرى نتايج

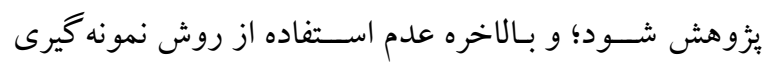
تصـادفى، محدوديت ديخر اين مطالعه بوده اسـت كه بايد در تعميم يافته ها با احتياط عمل كرد. در راســتاى نتايج بهدســت

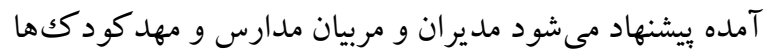

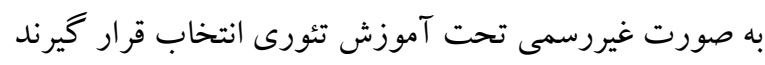

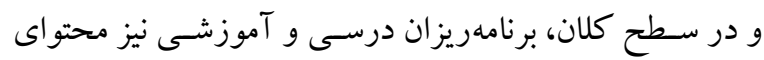
تئورى انتخاب را در قالب درس هاى مختلف مانند مهارتهاى

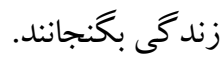

اجتماعى به واسطهه تقليد و تقويت آموخته مىشـود وكودكان يرخاشـخرى را از بزر گسـالان آموخته و تقليد مى كنند. كلاسـر

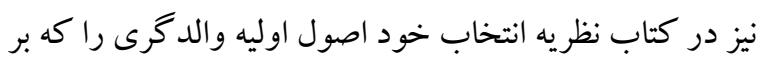
نظريه انتخاب مبتنى اسـت، عشـق و محبت بسـيار و عدم تنبيه معرفى كرده اسـت؛ در نتيجه وقتى كود كان، كمتر شاهد رفتار

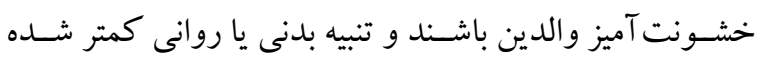

باشند، رفتارهاى يرخاشخر انه كمترى نشان مى دهند (YF).

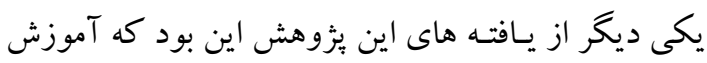

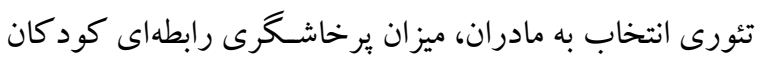
را كاهش داده اسـت كه بر اسـاس ديدكاه كلاسـر قابل تبيين اسـت. اين متخصص تئورى انتخاب معتقد است: بيش از هفت

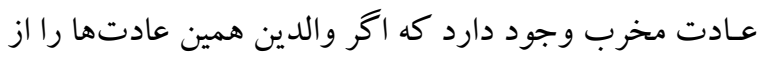

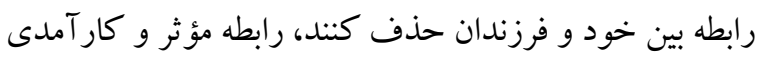
بين آنها برقرار مىشـود، در غيراين صـورت رابطه به اندازهاى تخريب مى شود كه هيج امكانى براى احياى آن وجود نخو اهد

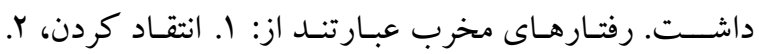
ســرزنش كردن، س. شــكوه كرده، F. نق نق كردن، ه. تهديد كردن، 4. تنبيه كردن، و V. باج دهى يا حق حساب دادن (Y) (Y). در نهايت زمانى كه والدين رفتارهاى مخرب رابطه را از رفتار خود حـذف مى كنــد و وظـايف خود را در ارتبـاط با فرزندان

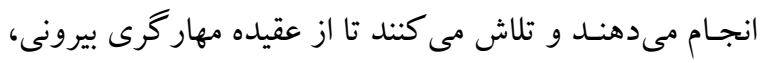
در رفتـار بـا فرزنـدان خود اجتنـاب كنند، از بروز شــكاف در

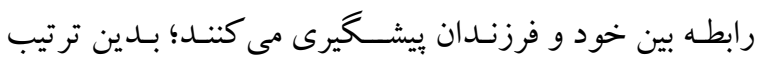
تئورى انتخـاب نيز تبـديـل به يكك الكوى رفتارى در كود وركان

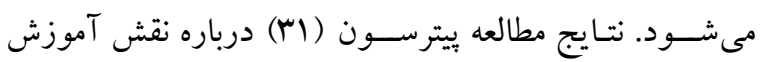
شيوههاى والدگرى صحيح به والدين بر كاهش رفتارهاى ضد

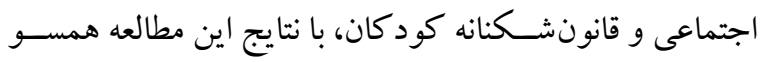

نتـايج تحليـل دادهها در اين مطالعه نشــان داد كه آموزش كأن تئورى انتخاب در كاهش بعد تكانشـى تأثير معنادارى نداشـته

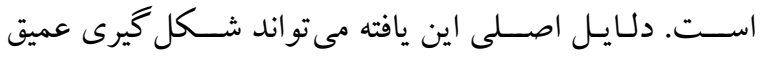
روانبنها در كود كك باشد كه به دليل روابط طولانى مدت والد بلد 
آموزشويرورش به خصوص كارشناس هسته مشاوره كه هماهنكى للازم با مدارس جهت آموزش والدين و انجام اين يزوهش را ان انجام دادند و همجنين از كادر ادارى، مربيان مدارس، و افراد نمونه كه در اجراى اين طرح به ما كمك كردند، تشكر و قدردانى مى شود.

تضــاد منــافع: در اين مطـالعه هيج گونه تعارض منافع توسـط

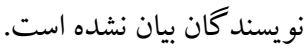

تشـكر و قدردانى: اين بُرهش بر گرفته از باياننامه كارشـناسى

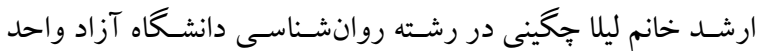
همدان با راهنمايى دكتر محمد اسـماعيل ابر اهيمى و مشـاورت على

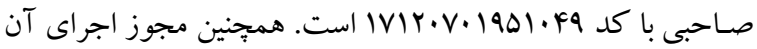
بر روى افراد نمونه از سـوى اداره آموزشو برورش ناحيه ا شهـر

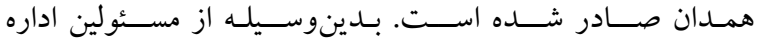




\section{References}

1. Zamani N, Ansari Shahidi M. Prevalence of psychological disorders among caregivers of children with intellectual disabilities and motor disabilities in Hamadan. Quarterly Journal of Child Mental Health. 2017; 4(3): 119-129. [Persian]. [Link]

2. Zamani N, Zamani S, Habibi M, Abedini S. Comparison in stress of caring mothers of children with developmental, external and internal disorders and normal children. Journal of Research \& Health. 2017; 7(2): 688- 694. [Link]

3. Dowdell EB. Caregiver burden: grandmothers raising their height risk grandchildren. J Psychosoc Nurs Ment Health Serv. 1995; 33(3): 27-30. [Link]

4. Faraone SV, Biederman J, Lehman BK, Spencer T, Norman D, Seidman LJ, et al. Intellectual performance and school failure in children with attention deficit hyperactivity disorder and in their siblings. J Abnorm Psychol. 1993; 102(4): 616-623. [Link]

5. Modabernia M, Shojaie Tehranie H, Falahi M, Faghirpour M. Normalizing SCL-90-R inventory in Guilan high-school students. Journal of Guilan University of Medical Sciences. 2010; 19(75): 58-65. [Persian]. [Link]

6. Stansfield SA, Marmot MG. Social class and minor psychiatric disorder in British Civil Servants: a validated screening survey using the General Health Questionnaire. Psychol Med. 1992; 22(3): 739-749. [Link]

7. Zare H, Khaleghi Delavar F, Zare M, Shayeghian Z. Effect of mindfulness in reducing aggression and impulsivity in adolescents. Journal of Research \& Health. 2016; 6(1): 113-121. [Link]

8. Koegel RL, Schreibman L, Loos LM, Dirlich-Wilhelm H, Dunlap G, Robbins FR, et al. Consistent stress profiles in mothers of children with autism. J Autism Dev Disord. 1992; 22(2): 205-216. [Link]

9. Zamani N, Abyar Z, Jenaabadi H, Zamani S. Effect of impulse control training on depression and anxiety mother of children with developmental coordination disorders. Journal of Research \& Health. 2017; 7(5): 1012-1020. [Link]

10.Movallali G, Barati R, Taheri M. Efficacy of social skills training on the reduction of verbal and nonverbal aggression in male students with intellectual disability. Quarterly Journal of Child Mental Health. 2015; 1(1): 57-66. [Persian]. [Link]

11. Abolmaali K, Mosavizadeh M. Aggressive, nature, causes and prevention (with annexand aggressive preventof Islam nature). Tehran: Arjmand; 2012, pp: 4-19. [Persian].

12. Mirzaei F, Hossein Khanzadeh AA, Asghari F, Shakerinia I. The role of family cohesion in prediction of aggressive behaviors of children. Quarterly Journal of Child Mental Health. 2015; 2(2): 73-84. [Persian]. [Link]

13.Ellis ML, Weiss B, Lochman JE. Executive functions in children: associations with aggressive behavior and appraisal processing. J Abnorm Child Psychol. 2009; 37(7): 945-956. [Link]

14. Riahi F, Amini F, Salehi Veisi M. The children's behavioral problems and their relationship with maternal mental health. Journal of Jahrom University of Medical Sciences. 2012; 10(1): 46-52. [Persian]. [Link]

15. Zamani N, Zamani S, Habibi M. A comparison between the effectiveness of dialectical and cognitive behavioral therapy on the mental health of mother. Journal of Research and Health. 2019; 9(1): 53- 61. [Link]

16. Glasser W. Stations of the mind: new directions for reality therapy. 1st edition. New York: HarperCollins; 1981, pp: 169-184. [Link]

17. Zamani N, Raeisi Z, Zamani S. Effect of group behavioral activation on depression, anxiety and stress in adjustment: three-case study. Journal of Research and Health. 2019; 9(3): 227-235. [Link]

18. Asghari F, Akbari B, Shadman R, Saadat S. The effect of cognitive-behavioral training on quality of life and aggression among drug addicted prisoners. Journal of Research \& Health. 2016; 5(4): 77-86. [Link] 
19. Lash JP, Wang X, Greene T, Gadegbeku CA, Hall Y, Jones K, et al. Quality of life in the African American Study of Kidney Disease and Hypertension: effects of blood pressure management. Am J Kidney Dis. 2006; 47(6): 956-964. [Link]

20. Shen B-J, Myers HF, McCreary CP. Psychosocial predictors of cardiac rehabilitation quality-of-life outcomes. J Psychosom Res. 2006; 60(1): 3-11. [Link]

21. Gross JJ, Barrett LF. Emotion generation and emotion regulation: one or two depends on your point of view. Emot Rev. 2011; 3(1): 8-16. [Link]

22. Moshirian Farahi SM, Moshirian Farahi SMM, Aghamohammadian Sharbaf HR, Sepehri Shamloo Z. The effectiveness of group reality therapy based on choice theory on quality of life in people with aggression. Iranian Journal of Psychiatric Nursing. 2017; 5(1): 47-53. [Persian]. [Link]

23. Gururaj G. Injury prevention and care: an important public health agenda for health, survival and safety of children. Indian J Pediatr. 2013; 80(Supplement 1): 100-108. [Link]

24. Glasser W. Choice theory: A new psychology of personal freedom. New York, NY, US: HarperPerennial; 1999, pp: 29-37. [Link]

25. De Villiers JG, De Villiers PA. The role of language in theory of mind development. Topics in Language Disorders. 2014; 34(4): 313-328. [Link]

26. Mahdiyanfar F, Kimiaei SA, Ghanbari Hashem Abadi BA. Examining the effectiveness of psychosocial empowerment based on choice theory on reducing depression and aggression in women with husbands in prison in 2014. Iranian Journal of Forensic Medicine. 2016; 21(3): 167-177. [Persian]. [Link]

27. Vandenabeele W. Explaining public service motivation: the role of leadership and basic needs satisfaction. Rev Public Pers Adm. 2014; 34(2): 153-173. [Link]

28. Kosno M. RECENZJA: self and social regulation. Social interaction and the development of social understanding and executive functions. Psychologia Rozwojowa. 2012; 17(1): 117-121. [Link]

29. Vahedi SH, Fathiazar S, Hosseini-Nasab SD, Moghaddam M. Validity and reliability of the aggression scale for preschoolers and assessment of aggression in preschool children in Uromia. The Journal of Fundamentals of Mental Health. 2008; 10(37): 15-24. [Persian]. [Link]

30. Endresen IM, Olweus D. Self-reported empathy in Norwegian adolescents: Sex differences, age trends, and relationship to bullying. In: Bohart AC, Stipek DJ, editor. Constructive \& destructive behavior: Implications for family, school, \& society. Washington, DC, US: American Psychological Association; 2001, p: 147-165. [Link]

31. Petersen S. Reality therapy and individual or Adlerian psychology a comparison. International Journal of Reality Therapy. 2005; 24(2): 11-14. [Link] 